\title{
Is the Delaware Court of Chancery Going "Objective” on Us? Or Policemen's Annuity and Benefit Fund of Chicago v. DV Realty Advisors LLC: More Delaware Permutations on Good Faith
}

Daniel S. Kleinberger

Mitchell Hamline School of Law, daniel.kleinberger@mitchellhamline.edu

Follow this and additional works at: https://open.mitchellhamline.edu/facsch

Part of the Business Organizations Law Commons

Publication Information

William Mitchell Legal Studies Research Paper No. 2012-12

\section{Repository Citation}

Kleinberger, Daniel S., "Is the Delaware Court of Chancery Going "Objective" on Us? Or Policemen's Annuity and Benefit Fund of Chicago v. DV Realty Advisors LLC: More Delaware Permutations on Good Faith" (2012). Faculty Scholarship. 514.

https://open.mitchellhamline.edu/facsch/514

This Article is brought to you for free and open access by Mitchell Hamline Open Access. It has been accepted for inclusion in Faculty Scholarship by an authorized administrator of Mitchell Hamline Open Access. For more information, please contact sean.felhofer@mitchellhamline.edu.

$\mathrm{MH}$

MITCHELL | HAMUINE OPEN ACCESS selod for the

mitchellhamline.edu 


\title{
Is the Delaware Court of Chancery Going “Objective” on Us? Or Policemen's Annuity and Benefit Fund of Chicago v. DV Realty Advisors LLC: More Delaware Permutations on Good Faith
}

\author{
Abstract \\ The Chancery Court's opinion in Policemen's Annuity and Benefit Fund of Chicago v. DV Realty Advisors \\ LLC, C.A. No. 7204-VCN, 2012 WL 3548206 (Del. Ch. Aug. 16, 2012) is thought provoking for at least two \\ reasons. The first is somewhat technical and concerns the relationship between a partnership \\ agreement's reference to "good faith" and the implied covenant of good faith. The second concerns what \\ appears to be yet another Delaware permutation on the meaning of "good faith." \\ Due to the opinion's treatment of the covenant, it seems possible (though hardly desirable) for two \\ different standards of good faith to apply to the exercise of discretion under an operating agreement or \\ partnership agreement - good faith as intended by the parties when they expressly subject discretion (or \\ other conduct) to "good faith" and good faith as irrevocably present in any limited partnership or operating \\ agreement per the LLC and LP statutes. \\ Even more thought provoking is the opinion's emphasis on the objective aspect of good faith. The court \\ quotes the UCC definition of the concept and then uses that definition to make its determination on the \\ merits. The opinion does not actually hold the UCC definition applicable but rather uses the definition for \\ an a fortiori analysis. Nonetheless, the favorable reference to the UCC definition should give transactional \\ lawyers pause. The objective notion of contractual good faith can occasion judicial second-guessing of \\ the most important aspects of deals.
}

\section{Keywords}

Good faith, Fair dealing, Contractual covenant, Contract interpretation, Limited liability company, Limited partnership, Chancery

Disciplines

Business Organizations Law 


\section{Is the Delaware Court of Chancery Going "Objective" on Us?}

or

Policemen's Annuity and Benefit Fund of Chicago v. DV Realty Advisors LLC:

More Delaware Permutations on Good Faith

(C) 2012 - Professor Daniel S. Kleinberger ${ }^{1}$

The Chancery Court's opinion in Policemen's Annuity and Benefit Fund of Chicago v. DV Realty Advisors LLC, C.A. No. 7204-VCN, 2012 WL 3548206 (Del. Ch. Aug. 16, 2012) is thought provoking for at least two reasons. The first is somewhat technical and concerns the relationship between a partnership agreement's reference to "good faith" and the implied covenant of good faith. The second concerns what appears to be yet another Delaware permutation on the meaning of "good faith."

\section{Defining Good Faith - Double Vision?}

In Policemen's Annuity, the court states: "Because the LPA provides that it 'is made pursuant to and shall be governed by the laws of the State of Delaware' the Court will presume that the parties intended to adopt Delaware's common law definition of good faith as applied to contracts." Policemen's Annuity, 2012 WL 3548206 at *13.

But suppose the parties had indicated otherwise? The contractual covenant of good faith would presumably still have applied, because that obligation can be delineated in a limited partnership or operating agreement but not eliminated. Del. Code Ann., tit. 6, §§ 17-1101(d) (LP act) and18-1101(c) (LLC act).

Thus, it seems possible (though hardly desirable) for two different standards of good faith to apply to the exercise of discretion under an operating agreement or partnership agreement good faith as intended by the parties when they expressly subject discretion (or other conduct) to "good faith" and good faith as irrevocably present in any limited partnership or operating agreement per the LLC and LP statutes.

Put another way, under Policemen's Annuity, express reference in a limited partnership or operating agreement to "acting in good faith" is - conceptually at least - distinct from the implied obligation to act in good faith.

\footnotetext{
${ }^{1}$ Professor of Law, William Mitchell College of Law; A.B. 1972, Harvard University; J.D. 1979, Yale Law School. Reporter, Uniform Law Conference Drafting Committee on Series of Unincorporated Business Entities; Co-Reporter, Uniform Law Conference Project for Harmonization of Business Entity Acts; daniel.kleinberger@ wmitchell.edu ; http://ssrn.com/author=329071. As always, my work depends fundamentally on the love, support, and insights of Carolyn C.S. Kleinberger, artist and recovering public defender.
} 
Take a fanciful example, just for the sake of illustration. Suppose the operating agreement expressly requires specified acts to be done in good faith and then defines good faith as "consultation with a Ouija board." Arguably at least, that definition applies to the express "good faith" obligation.

However, the definition will not suffice to control the implied obligation; reliance on a Ouija board is tantamount to "eliminate[ing] the implied contractual covenant of good faith and fair dealing." Del. Code Ann., tit. 6, §§ 18-1101(c) (LLC act) and 17-1101(d) (LP act). (Gerber v. Enterprise Products Holdings, LLC, C.A. No. 5989-VCN, 2012 WL 34442 at *12 (Del.Ch. January 6, 2012) is not to the contrary, unless one deems a Morgan Stanley Fairness Opinion as equivalent to consulting a Ouija board.)

\section{Emphasizing Objective Good Faith? In Delaware????}

Even more thought provoking is the opinion's emphasis on the objective aspect of good faith. The court quotes the UCC definition of the concept and then uses that definition to make its determination on the merits.

6 Del. C. § 1-201(20), which applies to contracts involving "goods," provides: "'Good faith', except as otherwise provided in Article 5 [which deals with letters of credit], means honesty in fact and the observance of reasonable commercial standards of fair dealing." The definition prescribed in 6 Del. C. § 1-201(20) is at least as broad of a definition of good faith as that applied to contracts at common law, and, as discussed below, the Limited Partners can meet the definition of good faith in 6 Del. C. $\S 201(20)$.

Policemen's Annuity, 2012 WL 3548206 at *13 [brackets in original].

The opinion does not actually hold the UCC definition applicable but rather uses the definition for an a fortiori analysis. Nonetheless, the favorable reference to the UCC definition should give transactional lawyers pause. Remember K.M.C. Co., Inc. v. Irving Trust Co. 757 F.2d 752, 760 (6th Cir.1985)? A lender's decision to stop lending and demand repayment was subject to the UCC concept of good faith and fair dealing - i.e., to "limitations of reasonableness and fairness." The lender's genuine subjective belief of insecurity was insufficient justification for the lender's actions.

The objective notion of contractual good faith can occasion judicial second-guessing of the most important aspects of deals. Which of the following statements is most likely to prevent such judicial "second guessing"?

The common law definition of good faith as applied to contracts is primarily subjective, but there is likely some conduct which is so unreasonable that this Court will necessarily determine that it could not have been undertaken in good 
faith. That may be because the common law definition of good faith as applied to contracts contains an objective element or it may be that, regardless of the evidence presented as to subjective intent, the Court will necessarily (almost always) find that certain conduct could not possibly have been undertaken in good faith. Articulating with precision what specific conduct will fall into this category is not possible. Context matters-what is utterly unreasonable in one setting may be perfectly acceptable in another.

[T] he obligation of good faith and fair dealing is not a fiduciary duty, does not command altruism or self-abnegation, and does not prevent a partner from acting in the partner's own self-interest. Courts should not use the obligation to change ex post facto the parties' or this Act's allocation of risk and power. To the contrary, the obligation should be used only to protect agreed-upon arrangements from conduct that is manifestly beyond what a reasonable person could have contemplated when the arrangements were made.

The operating agreement or this Act may grant discretion to a member or manager, and that person may properly exercise that discretion even though a member suffers as a consequence. Conduct does not violate the obligation of good faith and fair dealing merely because that conduct substantially prejudices a party. Indeed, parties allocate risk precisely because prejudice may occur.

The exercise of discretion constitutes a breach of the obligation of good faith and fair dealing only when the party claiming breach shows that the conduct has no honestly-held purpose that legitimately comports with the parties' agreedupon arrangements. Once such a purpose appears, courts should not second guess a party's choice of method in serving that purpose, unless the party invoking the obligation of good faith and fair dealing shows that the choice of method itself lacks any honestly-held purpose that legitimately comports with the parties' agreed-upon arrangements.

In sum, the purpose of the obligation of good faith and fair dealing is to protect the arrangement the partners have chosen for themselves, not to restructure that arrangement under the guise of safeguarding it.

The first formulation is now Delaware law, Policemen's Annuity and Benefit Fund of Chicago v. DV Realty Advisors LLC, 2012 WL 3548206 at *13 (footnotes omitted). I am reminded of a comment to the Revised Uniform Partnership Act: “'Good faith' clearly suggests a subjective element, while 'fair dealing' implies an objective component. It was decided to leave the terms undefined in the Act and allow the courts to develop their 
meaning based on the experience of real cases.” RUPA $\S 404$, cmt. 4. ${ }^{2}$ Hardly a buttress to predictability.

The second formulation comes from the comments to the 2011 revision of the Revised Uniform Limited Liability Company Act.

Is the ULC speaking more conservatively than the Delaware Court of Chancery?

${ }^{2}$ As part of the Uniform Law Conference Project for Harmonization of Business Entity Acts, the RUPA comment is being re-written to conform with the comment to ULLCA, quoted below in the text. 


\title{
Mitchell Hamline Open Access
}

Mitchell Hamline Open Access is the digital archive of Mitchell Hamline School of Law. Its mission is to preserve and provide access to our scholarly activities, for the benefit of researchers and members of the legal community.

Mitchell Hamline Open Access is a service of the Warren E. Burger Library.

open.mitchellhamline.edu

\author{
$\mathrm{MH}$ \\ MITCHELL | HAMLINE \\ School of Law \\ (C) Mitchell Hamline School of Law \\ 875 Summit Avenue, Saint Paul, MN 55105 \\ mitchellhamline.edu
}

